УДК 821.163.41.09

https://doi.org/10.18485/godisnjak.2018.13.4

\author{
Александра М. Угреновић* \\ Филолошки факултет \\ Универзитет у Београду
}

Оригинални научни рад

Примљен: 14. 09. 2018.

Прихваћен: 15. 10. 2018.

\title{
АНАТОМИЈА СИЖЕА У ПРОЗИ СРПСКОГ РЕАЛИЗМА**
}

\begin{abstract}
Радом се пружа преглед неколико основних и уједно најрелевантнијих начина сижејне творбе у прози српског реализма. Предочава се функција и поступак образовања синкретичког, класичног (линеарног), фолклорно-митолошког (циклично-кумулативног), хроничарског, провинцијског, моноваријантног и поливаријантног типа сижеа, уз аргументацију која се ослања на прозу репрезентативних писаца у поетици српског реализма.
\end{abstract}

Кључне речи: сиже, реализам, Ј. Игњатовић, Ј. Г. Миленко, С. Сремац, Л. Лазаревић, С. Матавуљ, Р. Домановић, И. Вукићевић, С. Ранковић.

Безграничност сижејне разноврсности у реалистичкој прози у суштини је илузорна, приметио је Ј. М. Лотман, што даје повода покушају да се из ње издвоје, свакако без претензије на исцрпност и коначност, типолошки модели који се регуларно понављају. Сижејна разноврсност и варијативност у реалистичкој прози се по принципу обрнуте сразмерности компензују ојачавањем константи и инваријанти у образовању сижеа. Зато је дезоријентација у сусрету са бахтинском незавршеном савременошћу изазвала регенерацију архаичних форми фолклорно-митолошких сижеа

*ugrenovic.sasa@gmail.com

** Истраживање је представљено на научном скупу Поетика српског реализма одржаном у децембру 2015. године на Филолошком факултету у Београду. 
и сижејних стереотипа. Услед комплексности проучавања сижејне творбе у науци у књижевности, типолошки преглед сижеа у поетици српског реализма биће овом приликом искључив у ограниченом избору сижејних типова и аргументован освртом на прозу репрезентативних писаца.

Проблем сижејности у књижевности условљен је третманом уметничког времена. Када време тече „отворено” у спрези са историјским временом, тада се слободно могу мешати временске линије а последичност догађаја се може измештати (нпр. прво се приповеда о последњим, а потом о исходишним догађајима; поступак ex abrupto, задржана експозиција или регресивни расплет). Сва премештања и сви временски пореци одвијају се на фону историјског времена, догађаји су поткрепљени у реалном времену, а иза њих се налази историјска последичност. Када је време затворено у себе, као у фолклорној традицији, тј. када није повезано са историјским временом, премештање догађаја и мешање различитих сижејних линија је отежано, уколико не постоји историјски фон који би догађајима дао последичност, нарушену испремештаним временским одсечцима. У фолклорној књижевности може бити речи о ствараоцу, приповедачу, казиваоцу, али пошто у њој нема аутора, не може бити ни ауторског времена, пише Д. С. Лихачов (1972), толико неопходног елемента књижевног дела. А ако нема ауторског времена као посебне временске позиције из које се води приповедање, онда нема могућности да се маневрише приповедним временом, примера ради, наративним техникама проспекције, аналепсе, елипсе, тропизације и сл. Тако у фолклорном реализму М. Глишића, J. Веселиновића, С. М. Љубише или знаменитој приповеци Ј. Г. Миленка постоји временски процеп који омогућава пролаз ка другом, условном свету, где догађаји протичу у условном времену. На плану сижеологије фолклорно сижејно време, затворено и статично, дијаметрално је супротно реалистичком сижејном времену, отвореном и слободном да се прелије иза граница сижеа у јединствени проток историјског времена. Условно време у фолклорним анегдотама и шаљивим причама (онима које су подлегле процесу новелизације) не одступа од свог јединственог, једнолинијског усмерења. Прича чува последичност догађаја и не сналази се са дигресивним одступницама и прекидима, а уколико се оне и појаве, рецимо, у форми наративног сказа, „ефекат реалног” се знатно повећава, јер у позадини статира њему супротно условно, неисторијско време.

Рачунајући на непомирљивост фиктивног и фактичког времена, писци склони фолклорној имагинацији користе очевидну некомпатибилност условног (фолклорног) и историјског (реалистичког) времена, не би ли обновили добро познату литерарну конвенцију синкретичког 
сижеа. Синкретички сиже је синкретичан са својим предметом: догађај приповедања (сиже) није одвојен од исприповеданог догађаја (фабуле), који је опет са своје стране синкретичан са стварношћу. Синкретички сиже функционише, дакле, по принципу сиже = фабула = стварност. У $\mathrm{XX}$ глави првог дела Дон Кихота Санчо Панса, причајући бајку о томе како је пастир пребацио тридесет коза с једног брда на друго, моли Дон Кихота да помно броји козе, да не погреши и да га не прекида у приповедању јер ако га прекине и ,ако само једну сметне са ума, завршиће се прича, и више ни реч неће моћи да исприча". Када Дон Кихот прекине свог штитоношу речима „рачунај да их је све пребацио”, прича је, како каже Санчо, истог момента окончана. Предности синкретичког сижеа можда је најупечатљивије упослио Грчић Миленко у приповеци $У$ гостионищи 'Код полузвезде' на имендан шантавог торбара.

Примера ради, у Грчићевој знаменитој приповеци или хумористичким романима С. Сремца условност „затвореног” сижејног (фиктивног) времена се спаја са историјским (фактичким) временом, не би ли створила илузију одигравања радње у моменту писања дела. Илузија поклапања сижејног и ауторског времена провоцира игру са наративом у духу својеврсне фолклорне верзије драмског правила о ,јединству времена” (в. Лихачов 1972). У прози фолклорног реализма, али и Матавуљевом и Сремчевом прозном изразу усидреном у фолклорном реализму, фолклорно време не подразумева само приповедање о догађајима, него и имитирање/импровизовано предочавање догађаја или игриво учествовање у њима, што је незамисливо за историјско реалистичко време које не трпи понављања тј. редупликације сижејног догађаја које иза себе не остављају стварносне (,реалне”) консеквенце.

Лихачовљевој теорији уметничког времена кореспондентна је теза о „наративном кретању” Ж. Женета, разуме се, у посве другачијој методолошкој оптици. „Наративно кретање” Женет посматра као однос „изохроније” и „анизохроније” тј. поклапања и непоклапања „времена сторије” (temps d'histoire) и „псеудовремена приповедања" ([pseudo] temps de récit). Уколико се та два времена поклапају, реч је о фолклорном затвореном времену, будући да је уметничко време фолклорних жанрова увек затворено за историјску димензију и строго ограничено (почиње оног тренутка када почне казивање и завршава се са окончањем казивања). Или пак о уметничком времену у модерној прози које синхронизује приказивање растегнуте радње и технику успореног приповедања (нпр. као У потрази за изгубљеним временом). Лихачов ће навести пример уметничког времена у обредној поезији, која своју фиксацију на садашње време користи 
не би ли премостила зјап између стварности и уметности, што би било аналогно поступку имитативног сказа у прози. Како због одсуства аутора у фолклорној традицији не постоји могућност да се на време радње гледа из неке одређене временске перспективе, садашње уметничко (,псеудовреме приповедања”) и садашње референцијално време („време сторије”) привидно се изједначавају (изохронија), све са намером да се постигне илузија поновне рекреације онога што се тог тренутка у фолклорном (и фолклоризованом) тексту збива. У питању је, примећује Лихачов, не само импровизација, већ и инсценација исприповеданог, тако да се посматрачи или слушаоци преобраћају у учеснике.

За фолклорни наратив који се конструише из неколико епизода, у зависности од промене места радње или функције јунака, специфична појава је предикативност мотива, својство за које је Ј. Мелетински предложио назив једночински микросиже. То је тенденција „постваривања” мотива, када се из мотива непосредно изводи сижејно приповедање. Када је мотив предикативан, тј. када покреће радњу, на пример, мотив ђавола, вампира или демонске силе, он често својом самодовољношћу и динамизмом запоставља непредикативне елементе у приповедању, дескриптивне, рефлексивне мотиве статичног типа. Пошто је мотив предикативна основа за развијање сижејног приповедања, од њега као предиката зависе актанти (агенс, пацијенс) и њихов број, због чега се за једночински микросиже најчешће бира анегдотско приповедање и поступак развијања пословица, народних изрека и паремија, где је субјекат (јунак/агенс) потпуно потчињен и зависан од предиката. У чистом облику такав фолклорни једночински микросиже тешко је, ако не и немогуће наћи у прози српских реалиста, осим ако није реч о приповедању „на народну”, што опет излази из оквира реализма. Како фолкорни једночински микросиже не може у поетици реализма постојати у чистом облику, категорија мотива-микросижеа у приповеткама фолклорног залеђа претпоставља тема-рематско јединство ${ }^{1}$. Посреди је мотив који не садржи само нешто познато (тему из познате фолклорне традиције), већ саопштава и нешто ново (рему из реалистичког мимезиса). Сиже се образује од теме, на пример, фолклорно маркираног догађаја који се, затим, обликује у контексту нове ситуацијереме из реалистичког проседеа. Примера ради, психолошко-социјална

${ }^{1}$ Тема-рематски принцип предикативности мотива, о којем се пише у савременим сижеолошким студијама, изворно потиче од двочланог модела А. Веселовског (a+б) и Ј. Мелетинског, чије концепције, свака за себе, припадају онтолошкој теорији сижеа (више о томе в. Тюпа В. И., Ромодановская Е. К. „Словарь мотивов как научная проблема”. От сюжета к мотиву. Новосибирск, 1996: 8). 
мотивација (рема) демонолошког предања (тема) у прози М. Глишића и J. Веселиновића, епски мотив опроштаја Бановић Страхиње (тема) у нехеројском контексту и неепском времену (рема) у приповеци Учини као Страхинић С. Матавуља, народне пословице којима се митско и колективно мишљење (тема) сужава до конкретно-индивидуалног искуства (рема) у Љубишиној прози итд. У прози фолклорних реалиста тематско-рематски мотив (микросиже) био је делотворна сижејногена јединица из које се развијао сиже, али у прози високог реализма исту сижејногену функцију ће убрзо преузети стил, морфологија јунака и инваријантни лутајући сижеи из литерарних залиха европске књижевности.

Тако једна од могућих типологија сижеа претпоставља поделу на моноваријантне и поливаријантне сижее. Моноваријантни сиже је схема која претпоставља да се догађај десио једанпут, искључиво у једној варијанти, што је својеврсни начин постизања миметизма у књижевности, рецимо, у цртицама, сликама, путописним приповеткама, етнографским и историјским романима и приповеткама, календарским причама или пак прози која је условљена традиционалним кодексом понашања и моновалентном етиком, на пример, у црногорским етосом строго омеђеној прози С. М. Љубише, М. Миљанова и С. Матавуља. У поливаријантном (потенцијалном) сижеу, спрам тога, један догађај постоји у неколико варијаната, те питање „Шта се заиста догодило?” звучи несувисло. Такво питање тражи веродостојност, „копију” животне стварности, а управо се она у поливаријантном сижеу нарушава ${ }^{2}$. Минимални услов за образовање поливаријантног сижеа или потенцијалног ауторског сижеа постоји већ при увођењу традиционалних књижевних мотива који у даљем развоју догађаја изневеравају књижевном праксом стечена очекивања. Поливаријантни сижеи су посебно функционални у Грчићевој приповеци са полидијегетичким нивоима, Сремчевим романима који негују „поетику уха" и гласина, приповеткама С. Матавуља са типовима казивалаца-хвалисаваца који „лажу и паралажу”, Вукићевићевој антибајци Прича о селу Врачима и Сими Ступищи уз граничарске приповетке, особено Мишка

${ }^{2}$ Проблем поливаријантности у поетици реализма назначен је у тексту Изазови реалистичке приче Д. Иванића, где аутор указује на неколико релевантних поставки проблема: а) постојање „могућих а ненаписаних приповедака” Л. Лазаревића, које аутор препознаје у скицама и парафразама фабула у пишчевој заоставштини; б) „скриптибилни” хронотоп код Матавуља; в) лик у позном реализму постаје „темпорална, плурална, процесуална категорија, све до проблематизовања идентитета”, јер је „реалистичка прича открила и фиксирала плурализам слике свијета", отворивши простор за оно што је наговестио већ романтизам, наиме, за „улазак паралелних и алтернативних свјетова”. Тако реалистичка прича више не потврђује стварност, већ ,алтернира или оспорава познате, конвенционалне стварности” (Иванић 2007: 169-179). 
Убојииу, али и појединим приповеткама С. Ранковића, попут Старог врускавиа. Поливаријантни сиже се често образује када се аутор двоуми око судбине јунака, те отвара неколико сижејних могућности којима се смрт или друга фатална околност може протумачити. Он отвара прозни текст према вансижејној (нпр. Све ће то народ позлатити) или још неартикулисаној сижејној могућности (нпр. Ветар). Тај аспект поливаријантне сижејне стратегије вероватно су најсавесније и најдоследније применили Лаза Лазаревић, такође у Вертеру и Швабици, и Симо Матавуљ понајпре у београдским причама. Још један могући начин откривања поливаријантности сижејног приповедања је праћење онтогенезе сижеа (период постепеног уобличавања сижеа од идеје до материјализације у тексту), која би се могла посматрати као подниво генетичке критике. Онтогенеза сижеа се прати поређењем редакција, посебно када писац испољава склоност ка сажимању, а заправо све пажљивијем сакривању сижеа, или када текст има два алтернативна расплета, од којих је један коначни или пак два расплета која постоје упоредо, уколико писац није начинио коначни избор. За испитивање поливаријантног сижеа постоји основа и када је књижевно дело остало незавршено (нпр. Бакоња фрра Брне) или, у ређим случајевима, када се читаоцу препушта задатак да заврши и домисли дело.

Укратко, поливаријантна сижејна схема подразумева контингенцију, односно, контингентни догађај који се ,десио, иако је могао и да се не деси" (Лотман 1970: 285), док би контингентни сиже укључивао догађаје који нису нужно ни могући ни немогући, који се могу али не морају остварити (сижејна контингентност, подсетимо, код Аристотела значи да оно што се замишља може бити и не бити). Смисао контингентности поливаријантног сижеа је готово увек апел за укидање фатализма и детерминисаности. Само неки од примера су полемика са историјским чињеницама у псеудоисторијским романима Ј. Игњатовића ${ }^{3}$, или са биолошким детерминизмом у Вечитом младожењи и Ранковићевом Горском цару, или са догађајима окошталим у литерарним конвенцијама у Швабищи и Верmеру. Слободни поливаријантни сиже иде мимо уцртаног пута који јунаци очекују за себе на основу прочитаних сентименталних романа (или било ког другог књижевног модела), примера ради, у Лазаревићевом Вертеру или Сремчевом Поп Ћири и поп Спири. Богато пространство сижејних могућности није дужно да се у реалистичкој прози преобрази у „реалну” радњу. Велико „може бити” као могућа паралелна сижејна линија скреће

${ }^{3}$ Као пример реализације „могућег сижеа”, којим се урушава детерминисаност, издвајамо псеудоисторијске романе Јакова Игњатовића, свакако изван поетике реализма (в. Јовићевић 2007). 
пажњу у Грчићевој чудесној згоди, у епилозима и епизодама са меланхоличним затишјем Сремчевих романа, у Матавуљевом Бакоњи фра Брну и његовим причама са лажним и нултим крајем, Лазаревићевом Ветру, Вукићевићевом Мишку Убојици и антиутопијској сатири, Ранковићевом Горском иару, Богомољиу или Старом врускавиу. О покушају да, али о укидању фатализма или детерминизма не може бити речи ни у једном од наведених примера, у супротном бисмо били ускраћени за хуморну меланхолију Стевана Сремца и „трагичке видове” Игњатовићевих социјалних романа, а понајпре за латентни трагизам сижеа Лазаревићеве, Матавуљеве, Ранковићеве и Вукићевићеве прозе. Напослетку, откривање вероватних, потенцијалних сижеа постоји са циљем да подстакне читаоца на мисао „могло је бити другачије” и да га наведе да пронађе конструктивно присуство могућих исхода који нису уобличени у тексту sensu stricto, али неупитно постоје.

Са проблемом поливаријантног сижеа у књижевности реализма изврсно кореспондира позната Бахтинова теза о томе да је „човек или изнад своје судбине или испод своје људскости" и да је захваљујући том „избитку људскости”, која превазилази судбину јунака, фикцијска стварност „само једна од могућих стварности, она није нужна, већ случајна и у себи носи друге могућности [...] Када је човек престао да се поклапа сам са собом, и сиже је престао да исцрпљује човека до краја" (Бахтин 1989: 470-471). Сходно томе, на сижејне резултате у прози наведених писаца се сасвим слободно може гледати као на једну од реализованих могућности, ону која ниуколико не исцрпљује сву стварност. Поједини Лазаревићеви, Матавуљеви, Сремчеви, Ранковићеви и Вукићевићеви јунаци се, будући „већи од своје судбине”, одиста одликују „избитком људскости” и оно што се са њима није догодило такође је извесна стварност - стварност нереализоване могућности. Она постоји у наративу као друга сижејна линија, тј. као могући сиже (М. Бахтин, С. Бочаров) или сижејно пространство (Ј. Лотман). Речју, поливаријантни сиже настаје када писац свесно остави у тексту траг других могућих исхода, или како је Л. Н. Толстој писао: „Смишљати и промишљати све што се може догодити са јунацима књижевног дела у настајању [...] и смислити милионе могућих исхода, само да би се изабрао један веома је тешко. Тиме се ја бавим" (Толстой 1978: 405). И Пол Рикер је веровао да постоје „(још) неиспричане повести” које је назвао „потенцијалне повести”. Одломци проживљених прича, снова, сећања - из тих крхотина треба извући ,једну причу која је у исти мах најнеподношљивија и најсмисленија" (Рикер 1993: 99). Попут Поварете Симе Матавуља. 
Примера ради, фабула у Бакоњи фра Брну оставља утисак да је Бакоњина судбина тек једна у низу могућих сижејних варијаната које су наговештене у назнакама нереализованог сижеа васпитног, социјалног, хроникалног или психолошког романа, парови јунака-двојника у роману Један разорен ум Л. Комарчића, трострука степенаста композиција у Ранковићевом Старом врускавиу, мрежа испреплетених мотивација у Горском изару, паралелна композиција и упарени јунаци у Игњатовићевим и Сремчевим романима су само неки од примера како се са сваком новом парном или паралелном и степенастом сижејном линијом отвара могућност за другачији исход, који ће ипак остати нереализован (судбина Шамике и Пере Кирића, учитеља Пере, Калче и Светислава, Лазаревићевог Јанка, судбина трију покољења Ранковићеве „хронике”, итд.).

Незавршене судбине јунака, непредсказиви и много богатији исходи и расплети од оних задатих конвенционалним литерарним мотивима, здраворазумском логиком и типским приповедним решењима задатак су поливаријантног сижеа. Овај тип сижеа пореклом из романтизма са доласком модернијих књижевних струјања биће изнова афирмисан, сада у форми симболичког сижеа (у српском реализму најчешће чеховљевско-мопасановске провенијенције), којим се емпиријско-свакодневни фон радње постепено замењивао естетизованом стварношћу. То није увек лако уочити, посебно у реалистичкој прози која апелује на „живот” и подстиче наивни утисак о непосредним аналогијама између уметничке стварности и њених референцијалних корелата. У поливаријантном сижеу се предност даје естетизованом а не референцијалном моделу ситуације. Тек ће у последњим двема фазама српског реализма бити јасно видљива оријентација на моделирање сижеа према иманентним законима саме књижевности, уместо на дотадашњу корелацију између догађаја и његовог вануметничког еквивалента. Сижејна ситуација у том случају није више подражавање и „копирање” животног догађаја, већ подражавање литерарног модела из којег се понекад могу извести бесконачне наративне могућности.

Један од најпробитачнијих начина за постизање поливаријантног сижеа, а особено симболичког јесте маневрисање „наративним кретањима” (mouvements narratifs), како их зове Ж. Женет. Укратко се проблем своди на питање селективности сторије (,дискурса”) према догађајима. „Растегнуто" приказивање успорава приповедање, а селекција невеликог броја елемената „сажима” приказивање како би се приповедање доживљававало као „брзо” и лаконско. „Растегнутост” и „сажетост” нису ништа друго до низак или висок степен селективности „дискурса” у односу на догађаје. Примера ради, догађаји који по природи заузимају дуг временски одсечак 
позиционирају се негде између епизода и њима се у најбољем случају посвећује кратак извештај о минулим годинама (,прошло је неколико година"). Такав низак степен селективности ће у Игњатовићевим романима образовати хроничарски сиже, чијом се усиљеном сажетошћу поручује да је свет само „таштина над таштинама” на коју не вреди трошити много речи. У исти мах, херметичност сижејне елипсе се избегава разуђеним приповедањем, односно, техникама које не припадају дијегези, већ екзегези (оцене, коментари, генерализације, рефлексије, аутотематизација наратора). Са друге стране, хроничарски сиже може пратити изразито висок степен селективности, посебно када писац жели да предочи априорну историјску епистему, што неретко резултира раскораком између равни садашњости и епске прошлости. Примера ради, у Љубишиној прози се историјско време сажима до пословице (Кањощ Мацедоновић) или елипсе (Продаја патријаре Бркића). Но, сажето приказивање пропраћено високим степеном селективности догађаја наћи ће се у посве другачијој функцији у фази зрелог реализма. Док се важним моментима у радњи Лазаревићевих, Матавуљевих, Вукићевићевих граничарских или појединих Ранковићевих приповедака не поклања очекивана пажња (нпр. честа је потпуна или делимична неодређеност психолошке или које друге мотивације), детаљи који у први мах изгледају безначајно добијају прецизну и темељну обраду. Крајње поједностављено, однос времена и селективности у сижејној творби се може представити једначином: сажетост + низак степен селективности $=$ хроничарски сиже; сажетост + висок степен селективности = поливаријантни (симболички сиже). Такав, рекло би се, немотивисан однос између сажимања и разуђивања, излишна детаљизација или пак несувисла сумарност приповедања у потоњем типу сижеа чине да приче изгледају као да су „голе” у епохи која је тражила подробно описана осећања а не „голе” догађаје. Међутим, убрзо је постало очигледно да пунктуална техника обраде времена омогућава да се на свега неколико страница оствари ефекат пуноће животног тока, управо посредством поливаријантне сижејне схеме која не захтева превише наративног простора. То је уједно разлог више зашто поједине прозне минијатуре наведених аутора подлежу поређењу са ,романима у малом”.

Класификација кардиналних типова сижеа (класични и митолошки сиже) Јурија Лотмана може немало допринети распрама о сижеологији у прози српског реализма. Лотман је, наиме, развио и допунио Хегелов концепт сижејне колизије општепознатом формулацијом сижејногеног догађаја: када јунак прекорачи границу семантичког поља, тј. наруши рампу (физичку, топонимску, временску, етичку, идеолошку и сл.) настаје 
догађај у тексту и неопходни услов за образовање класичног сижеа ${ }^{4}$. Сa друге стране, у основи митолошког сижеа не налази се нарушавање рампе; строго говорећи, нарушавање рампе овде није ни могуће. На поменуту типологију се својом подједнаком универзалношћу надовезује селекција сижеа на оне са кумулативним и оне са линеарним типом догађаја. Или, ако је реч о подели према принципу временског континуитета, на концентрични и хроникални тип сижеа. Тип сижеа који се заснива на центрифугалном догађају је кумулативни или митолошки/циклички сиже са следећим одликама: одсуство категорије почетка и краја (приповедање може почети из било које тачке и у било којој тачки се може завршити); изоморфност и хомеоморфност јунака (различита имена / маске истог типа јунака); свођење света ексцеса и аномалија на норму и стабилно устројство. Типолошки је овом моделу супротан тип текста са линијским временским током који фиксира случај, ексцес и нарушавање извесног поретка. Неопходно је нагласити да та два сижеа у чистом виду не опстају и да је савремени сижејни текст плод интерференције оба типолошка модела. У појединим случајевима се циклички сиже ангажује не би ли се образовао провинщијски сиже и пародија линеарног сижеа, примера ради, у антибајци Илије Вукићевића или алегорично-сатиричним причама Радоја Домановића. Посреди је пародија реалистичког линеарног сижеа (обележеног календарским временом), који предочава аномалије и ексцесе у њиховом нарушавању задатог поретка. Будући да у фази дезинтеграције српског реализма Вукићевић и Домановић претендују на приказивање слике света у којој друштвене аномалије постају правило, линеарни сиже више не служи сврси. Зато ће у духу антрополошког песимизма искористити циклични сиже не би ли показали како приказани догађаји из сфере религиозне, социјалне и политичке стварности нису никаква аномалија ни инцидент, већ трагична закономерност. У Вукићевићевој антиутопији и Домановићевим сатирама сижејни догађај је пресецање тополошке границе између два света, уместо семантичке, као у линеарном сижеу; у кумулативном ланцу догађаја размењују се „метонимије” јунака, тј. изоморфне маске главног јунака; време није календарско, већ митолошки циклично, а хронотопично уступа пред ахронотопичним приповедањем. По узору на митолошки циклични сиже, из морфологије главног јунака

${ }^{4} 3$ а формирање сижеа и развитак сижејне динамике неопходна је колизија, сматра Хегел, тј. догађај који урушава неки владајући поредак. Колизија је нарушавање које се не може дуго одржати у стању трансгресије, већ мора подлећи поновном успостављању хармоније. Тренутак колизије или садржајних противречности је моменат када фабула прелази у сиже, те се за сиже може рећи и да је „колизија у покрету”. 
се развија сижејна радња (нпр. Сима Ступица - Ћетен Мудрица, Ненад Убојица, Панта Васпитатељ, Наум Цинцарин...) а колизивну радњу, која урушава утврђени поредак и уводи трансгресију, замењује неколизивна радња која суштински ништа не мења. У исти модел кумулативне изградње сижеа, који се заснива на непротивречном типу догађаја, могу се уврстити и поједини романи Стевана Сремца (Поп Ћира и поп Спира, Ивкова слава) и Симе Матавуља (Бакоња фра Брне). Примера ради, сиже у Поп Ћири u non Cnири се гради кумулативним нарастањем ланца каприца парова изоморфних јунака, при чему је већина епизода семантички таутолошка. Морфологија јунака која изазива таутологију догађаја је основни закон митолошко-фолклорног сижејног поретка. Другим речима, када јунак чини само оно што сам семантички означава (Бакоња - бакочити се, поп Хала и поп Кеса, Курјак, итд.) посреди је пародирање или пак дезинтеграција линеарног (класичног) сижеа, као у наведеној прози И. Вукићевића и Р. Домановића, ангажовањем цикличног сижеа са неколизивним типом догађаја.

Провинцијски сиже је подтип кумулативног (цикличког) сижеа и релативно је стабилан комплекс којим се предочава једнообразни малограђански живот где свако свакога зна, где су људи или у свакодневном трвењу или у доброжитељној дружби, рецимо, у хумористичким романима С. Сремца и бокељским причама С. Матавуља (нпр. Нови свијет у старом Розопеку). Тако назначен семантички обзор провинцијског сижеа сужава очекивања, те се стиче дојам да ситничарство житеља провинције ограничава сижејне могућности. Но, Михаил Бахтин је својевремено запазио да је провинцијски хронотоп необично распрострањен у прози 19. века, описавши га као „густо, лепљиво време које мили простором”, преплићући се „са другим, нецикличним временским низовима”. Време провинцијских градића је цикличко време које подразумева постојано понављање ситуација. За Бахтина је

такав градић место цикличног свакодневног времена. Овде нема догађаја, има само „постојања” које се понавља. Време је овде лишено прогресивног историјског кретања, оно се креће у уским круговима: круг дана, круг недеље, круг месеца, круг читавог живота. Дан никада није дан, година није година, живот није живот. Из дана у дан понављају се исте животне активности, исте теме разговора, исте речи итд. Људи у том времену једу, пију, спавају, имају жене, љубавнице (пролазне), воде ситне интриге, седе у својим дућанима или канцеларијама, картају се, сплеткаре. То је уобичајено-свакидашње циклично време. Оно нам је познато у разним варијацијама од Гогоља и Тургењева, од Глеба Успенског, Шчедрина, Чехова. Обележја тога времена су једноставна, грубо-материјална, чврсто срасла са животним простором: са кућицама и собицама у градићу, сањивим улицама, прашином и мувама, клубовима, билијарима итд, итд. Време је овде без догађаја 
и зато изгледа готово заустављено. Овде нема ни „сусрета” ни „растанка”. То је густо, лепљиво време које мили простором. Зато оно не може бити основно време у роману. Њега романсијери користе као споредно време, преплићу га са другим, нецикличним временским низовима или га прекидају њима, оно често служи као контрасни фон за временске низове догађаја и енергије (Бахтин 1989: 377-378).

Међутим, када се из провинцијског сижеа уклони хронотоп са „високим емоционално-вредносним интензитетом”, хронотоп кризе, од жанра ће зависити да ли ће провинцијски сиже бити естетски високо функционалан или ниско функционалан. Према томе, одсуство хронотопа кризе у бокељским приповеткама је предност, јер је реч о кратком или релативно кратком жанровском блоку који се хумором може изборити са претећом монотонијом провинцијског сижеа, док у роману оно већ прераста у ниско функционални сиже који се одржава само захваљујући метасижејној равни.

На наведену Бахтинову мисао касније ће се надовезати наратолошка елаборација Волфа Шмида. Шмид је сижејни догађај, такође, видео као „фактичку и резултативну промену стања", која се тешко може приметити у провинцијском сижеу, јер одсуствују и други предуслови фабуларне догађајности: нема иреверзибилности, релевантности, непредвидљивости, консекутивности и непоновљивости догађаја (Шмид 2003: 11-13). Пошто се закономерна, предсказива промена не може назвати догађајем, провинцијски хронотоп ће постати сиже, али не на дијегетичкој (сижејној), већ на екзегетичкој (метасижејној) равни. Нулто значење тј. безрезултативност промена у провинцијском градићу имају сижеи у којима краткотрајни потреси, на пример, политички или љубавни избори ништа не мењају у сижејном току, јер ,промене које су тривијалне у рангу унутартекстуалне аксиологије не заснивају догађаје”, према речима В. Шмида. Ако је фабуларна раван у провинцијском сижеу квазидогађај, тада се значај догађаја преноси на метасижејну раван. Метасижејна раван провинцијског сижеа подразумева догађај казивања и усменог приповедања несижејног материјала, рецимо, у бокељској прози Симе Матавуља или догађај записивања стваралачког „сведочанства”, најпре у Роману без романа Јована С. Поповића, а потом и романима Стевана Сремца. Метасижејна раван показује путању којом несижејни догађај постаје сижејни, односно постаје део наратива и самим тим добија важност у „унутартекстуалној аксиологији”. У извесном смислу, екзегеза сижеа (метасижејност) уступа пред дијегезом сижеа.

Хроничарски сиже је подтип линеарног сижеа и својствен је псеудоисторијским и друштвеним романима Јакова Игњатовића, историјским романима Пере Тодоровића и хумористичким романима Стевана Сремца. 
Категорију уметничког времена у њиховим романима обједињује приповедач налик на хроничара или репортера који, изгарајући од жеље да сазна од сведока шта се догодило, ствара илузију писања „у ходу”. Игњатовића, Тодоровића и Сремца не привлачи фиксирана нараторска позиција у једној искључивој фокализацији. Њиховим приповедачима су неопходне најмање две тачке гледишта (од којих је једна хроничарска), јер се тек сменом фокализација постиже ефекат који Д. С. Лихачов назива ефектом доренесансног сликарства - јунаци и догађаји су приказани из неколико углова и перспектива. То је једна од предности илузије летописног времена и ангажовања приповедача-хроничара, „летописца савременог доба”. Корелат ефекту доренесансног сликарства у поетици српског реализма је поетика гласова која је изразито функционална код писаца који „вол(е) да догађај саопшт(е) по одјецима", како би ,један те исти чин доби(о) сасвим неподударне описе” (Иванић 2002а: 196). Гласине дају хроничарском приповедању оно што му је неопходно: од несижејне грађе, гласова као отворених сижејних могућности образује се сиже податан поливаријантној сижетици. У гласинама које „нису приче већ приче у настајању” приповедање се „ослобађа места, извора и личности” (Иванић 2002б: 87) те се гласинама по правилу не уобличава сиже, колико приповедање само себе анимира или провоцира (Иванић - Вукићевић 2007: 282).

Налик летописцу, Игњатовић, Тодоровић и Сремац придају подједнак значај важном и неважном, обједињујући оно што је значајно и прворазредно и за радњу другостепено и без особитог значаја. „Брзи летопис” романа, како Лихачов зове овај тип романа, није покушај архаизације приповедања или механичког васкрсавања заборављених форми уметничког времена. То је, примерице, Игњатовићева склоност ка стенограмском приповедању као савременој форми летописа, документованог записа који следи готово протоколарну тачност, а у трци за новим догодовштинама подсећа на Сремца. Притом, Игњатовић, Тодоровић и Сремац не теже да репродукују летописно време, које је било епско, колективно сазнање времена, они га само уграђују у глас приповедача-хроничара (уместо у догађаје) који излаже догађаје под ванвременским диктумом. Летописно време се, каже Д. С. Лихачов, заснива на механичком сједињавању, унутар једног хронолошког оквира, догађаја различитог калибра који су слабо повезани узрочно-последичном зависношћу, као да летописни сиже подсећа читаоца да је све „таштина над таштинама”. У Игњатовићевим псеудоисторијским романима, али неретко и друштвеним, механичко спајање различитих извештаја о догађајима истиче провиденцијалну тачку гледишта летописца, његову особену филозофију историје, очигледно, сујетност. Летописни 
сиже се овде неретко постиже поступком кумулације догађаја о којима се приповеда хронолошки и неселективно, пренебрегавањем психолошког портретисања јунака и тривијализацијом фабуле.

Ипак, хроничарски сиже има једну особину којом се мора пажљиво руковати, јер може бити како средство успешних естетских решења (најуспешнијих код Ф. М. Достојевског), тако и не баш срећног избора. Други случај, небрижљиво и исхитрено упошљавање хроничарског сижеа у романима Ј. Игњатовића, историјским романима Ј. Веселиновића и П. Тодоровића и хумористичким романима С. Сремца спречило је неговање и експанзију класичног реалистичког романа, између осталог, зато што поступци циклизације и кумулације као сижејни механизми не упијају историјско време, што значи да се сиже образује према догађају а не према типу јунака. За реалистички роман важно је да јунак буде, како Бахтин каже, променљива величина, незавршена величина која преузима прворазредни сижејни значај, уместо догађаја. То значи да је од кардиналног значаја да се јунак усклади са временским хронотопом (време преовлађује над простором, случај је у романима С. Ранковића), а не са просторним хронотопом (простор преовлађује над временом), којим се користи авантуристички, пикарски, хумористички, етнографски, па чак и историјски роман, као што је случај са тачкастим и линеарним хронотопом Игњатовићевих, Тодоровићевих, Веселиновићевих, Матавуљевих и Сремчевих романа.

\section{ЛИТЕРАТУРА}

Бахтин 1989: М. М. Бахтин, О роману, Београд: Нолит.

Иванић 2002а: Д. Иванић, Свијет и прича, Београд: Нолит.

Иванић 2002б: Д. Иванић, „Поетика гласова (Од гласова до приче)”, Книжевна историја, 116/117.

Иванић 2007: Д. Иванић, „Изазови реалистичке приче”, Зборник радова Српска реалистичка прича, Крагујевац: ФИЛУМ.

Иванић, Вукићевић 2007: Д. Иванић, Д. Вукићевић, Ка поетиции српског реализма. Београд: Завод за уџбенике.

Јовићевић 2007: Т. Јовићевић, Српски историјски роман 19. века, Београд: Друштво за српски језик и књижевност.

Лихачов 1972: Д. С. Лихачов, Поетика старе руске књижевности, Београд: СКЗ.

Лотман 1970: М. Ю. Лотман, Структура художественного текста, Москва: Искусство. 
Рикер 1993: П. Рикер, Време и прича, Нови Сад: ИКЗС.

Толстой 1978: Л. Н. Толстой, Переписка с русскими писателями, Том 1. Москва.

Шмид 2003: В. Шмид, Нарратология, Москва: Языки славянской культуры.

Александра М. Угренович

АНАТОМИЯ СЮЖЕТА В СЕРБСКОЙ ЛИТЕРАТУРЕ РЕАЛИСТИЧЕСКОГО НАПРАВЛЕНИЯ

$$
\text { Резюме }
$$

В статье рассматриваются некоторые основные, а также наиболее важные способы сюжетообразования в сербской литературе реалистического направления XIX столетия. Намерение заключается в том чтобы сосредоточить внимание на процессах образования синкретического, классического (линейного), мифологического (циклического/кумулятивного), хроникального, провинциального и возможного типа сюжета.

Ключевые слова: сюжет, реализм, Я. Игнятович, Й. Г. Миленко, С. Сремац, Л. Лазаревич, С. Матавуль, Р. Доманович, И. Вукичевич, С. Ранкович. 